\title{
Penerapan Teknologi Vacuum Seal untuk Meningkatkan Daya Tahan Produk Olahan Ikan di Sentra Ikan Bulak
}

\author{
Aida Annisa Amin Daman* | Wiwiek Hendrowati I Ari Kurniawan Saputra I Latifah Nurahmi
}

Departemen Teknik Mesin, Institut Teknologi Sepuluh Nopember, Surabaya, Indonesia

\section{Korespondensi}

*Aida Annisa Amin Daman, Departemen Teknik Mesin, Institut Teknologi Sepuluh Nopember, Surabaya, Indonesia. Alamat e-mail: aida@me.its.ac.id

\section{Alamat}

Laboratorium Rekayasa Vibrasi dan Sistem Otomotif, Departemen Teknik Mesin, Institut Teknologi Sepuluh Nopember, Surabaya, Indonesia

\begin{abstract}
Abstrak
Pemasaran produk erat kaitannya dengan cara pengemasan yang baik dan menarik. Satu hal yang perlu diperhatikan dalam pengemasan makanan yaitu pemilihan bahan pengemasan yang harus sesuai dengan jenis makanan itu sendiri. Permasalahan cara pengemasan ini dialami oleh pedagang ikan asap dan ikan segar di Sentra Ikan Bulak (SIB), Surabaya. Pembeli ikan di SIB terbatas hanya pada masyarakat sekitar Surabaya, sedangkan pembeli dari luar kota kurang berminat karena pengemasan ikan rawan bocor dan bau jika dibawa dalam perjalanan panjang. Sehingga teknologi pengemasan yang lebih modern dengan vacuum seal sangat diperlukan untuk mengatasi masalah tersebut. Publikasi ini melaporkan kegiatan pengabdian yang memberikan penyuluhan serta menerapkan teknologi vacuum seal kepada SIB sehingga produk olahan ikan dapat bertahan lebih lama dan penjualan ikan di SIB dapat meningkat.
\end{abstract}

\author{
Kata Kunci: \\ pengemasan, pemasaran, produk olahan ikan, teknologi, vacuum seal
}

\section{1 | PENDAHULUAN}

Sentra Ikan Bulak (SIB) yang terletak di pesisir utara Surabaya, tepatnya di Kecamatan Bulak, merupakan tempat yang menaungi pedagang dan Usaha Mikro Kecil dan Menengah (UMKM) dalam memasarkan produk-produk olahan hasil laut. Beberapa produk yang dipasarkan berupa aneka kerupuk ikan, ikan asap, ikan segar, dan aksesoris dari kerang. Tempat penjualan memiliki kondisi yang bersih dan teratur seperti ditunjukkan pada Gambar 1 a dan $1 \mathrm{~b}$, namun pedagang masih mengeluhkan jumlah pembelian luar kota yang sedikit terutama pada produk ikan asap dan ikan segar. Salah satu penyebab masalah ini adalah karena cara pengemasan produk yang masih menggunakan tas plastik biasa. Penggunaan tas plastik tersebut dinilai tidak efisien karena dapat menimbulkan aroma tidak sedap saat dibawa dalam mobil, serta air dari ikan rawan bocor selama perjalanan.

Permasalahan tersebut dapat diatasi dengan memperbaiki cara pengemasan produk ikan. Tata cara pengemasan suatu produk sebenarnya telah diatur dalam PP No.69 Tahun 1999 tentang Label dan Iklan Pangan [4]. Peraturan tersebut membahas beberapa variabel yang diatur berupa nama produk, bahan produk, tanggal kadaluarsa produk, dan keterangan-keterangan lain yang 


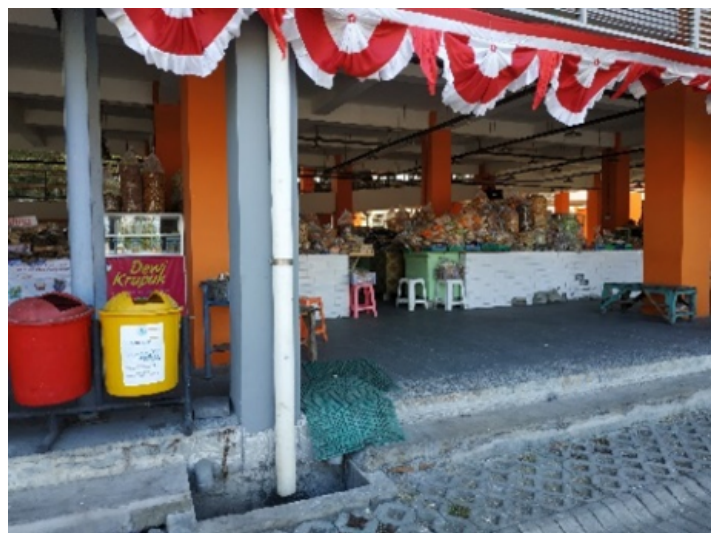

(a)

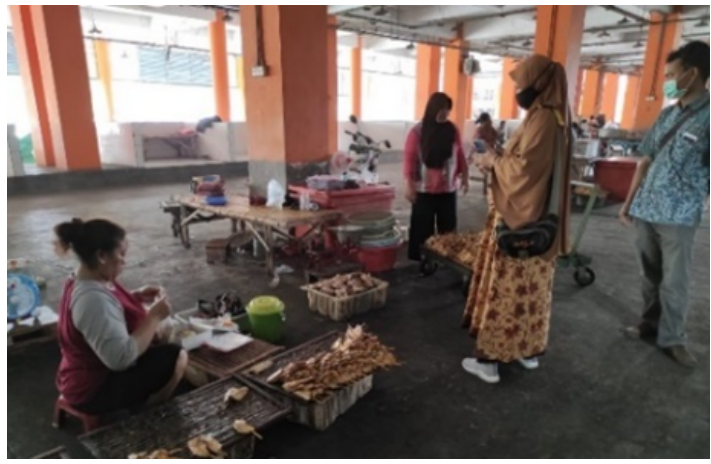

(b)

Gambar 1 Sentra Ikan Bulak, Surabaya, 1 a) kios ikan asap dan basah, 1 b kios kerupuk dan olahan ikan kering

perlu dicantumkan dalam kemasan produk. Syarat pengemasan yang baik yaitu tidak memiliki kandungan berbahaya (racun), melindungi produk dari kotoran, mikroba, dan faktor lain yang menyebabkan hilangnya volume produk, dan tahan terhadap perubahan suhu, kelembaban dan gesekan [6].

Penelitian mengenai perbedaan pengemasan sayur dengan kemasan plastik di temperatur dingin dan temperature ruang telah dilaksanakan oleh Mareta dan Shofia N [3]. Salah satu hasil yang diperoleh yaitu pada temperatur dingin, plastik polypropylene (PP) lebih mampu menjaga kesegaran sayuran daripada kemasan plastik polyethylene (PE). Penelitian serupa dilakukan oleh Nur [5] dengan bahan uji sate bandeng dan hasil menunjukkan bahwa plastik PP merupakan kemasan terbaik dengan waktu penyimpanan maksimal 6 hari. Selain material pengemasan, hal lain yang memengaruhi usia suatu produk yaitu teknik pengemasan. Beberapa teknik pengemasan yang digunakan yaitu heat sealer, vacuum packaging, dan alat pengemas bertekanan [3]. Harris dan Fadli [2] melaksanakan penelitian yang membandingkan teknik pengemasan vakum dan tanpa vakum dengan benda uji Pundang Seluang. Hasil yang diperoleh, masa simpan Pundang seluang pada pengemasan vakum lebih panjang sekitar 40\% daripada masa simpan pengemasan tanpa vakum. Penelitian mengenai kondisi dendeng ikan nila pada pengemasan vacuum telah dilaksanakan oleh Dewi dan Ibrahim [1] dan hasil menunjukkan kadar air turun, kadar TVBN tidak terpengaruh setelah 30 hari simpan, namun terdapat peningkatan jumlah koloni bakteri.

Berdasarkan permasalahan pengemasan yang dihadapi pedagang SIB, tim pengabdian masyarakat Departemen Teknik Mesin mengajukan "Penerapan Teknologi Vacuum Seal Dalam Meningkatkan Daya Tahan Produk Olahan Ikan" sebagai salah satu solusi. Kegiatan ini bertujuan untuk memberikan wawasan mengenai tata cara pengemasan dengan vacuum sealer dan membantu pedagang dengan menghibahkan alat vacuum sealer.

\section{2 | METODE KEGIATAN}

Kegiatan pengabdian masyarakat ini dilakukan dengan tahapan berikut: administrasi, studi literature, studi lapang, dan pemberian wawasan pengemasan. Kegiatan adminstrasi terkait dengan proses perizinan kegiatan karena kegiatan melibatkan UMKM di bawah Kecamatan Bulak, Kota Surabaya. Adapun alur administrasi proses perizinan dapat dilihat pada Gambar 2 Langkah pertama yaitu pengajuan surat kesediaan kepada Camat Bulak karena kegiatan pengabdian dilaksanakan di area Kecamatan Bulak. Surat kesediaan merupakan satu dari beberapa dokumen yang dibutuhkan untuk pengajuan izin kegiatan kepada Kepala Badan Kesatuan Bangsa, Penanggulangan Bencana, dan Perlindungan Masyarakat (BKBPB Linmas) Kota Surabaya. Surat rekomendasi dari Kepala BKBPB Linmas Surabaya dapat terbit Ketika seluruh persyaratan terpenuhi. Proses selanjutnya yaitu memberi informasi kepada Kecamatan Bulak bahwa tim pengabdi telah memperoleh izin kegiatan dari BKBPB Linmas Surabaya. Kemudian Camat Bulak memberikan disposisi pada staff bidang Ekonomi yang berhubungan langsung dengan UMKM di SIB. Kemudian, tim pengabdi mengirimkan surat peminjaman ruang kepada Dinas Ketahanan Pangan dan Pertanian sebagai koordinator SIB. Langkah terakhir yaitu pelaksanaan kegiatan. 


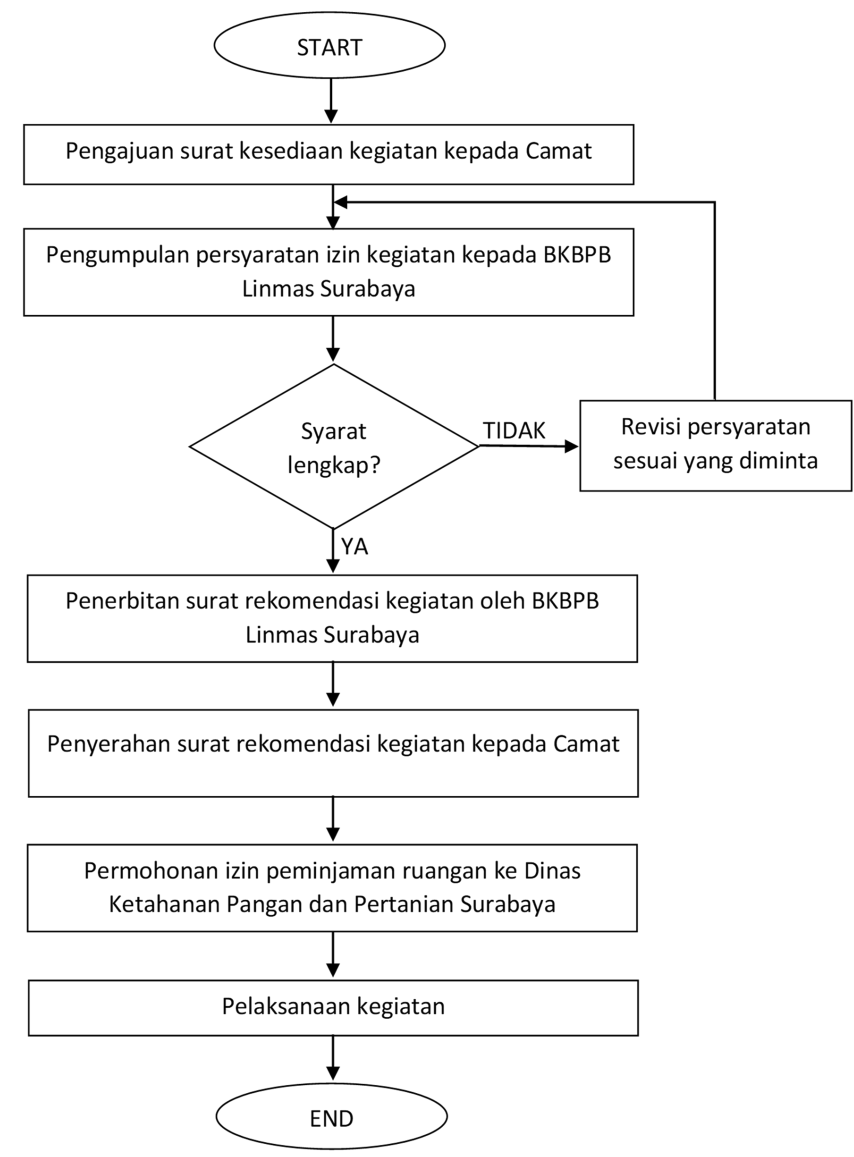

Gambar 2 Diagram alir proses adminstrasi kegiatan

Studi literatur dilaksanakan untuk mencari referensi mengenai pengemasan makanan yang telah dibahas pada pendahuluan. Tahap terakhir yaitu pemberian wawasan tentang kegunaan vacuum sealer dan demo alat. Vacuum sealer yang digunakan pada kegiatan ini merupakan vacuum sealer basah dengan dua ukuran yaitu panjang $30 \mathrm{~cm}$ seperti terlihat pada Gambar 3 dan panjang $28 \mathrm{~cm}$ dan lebar seal sebesar $4 \mathrm{~mm}$. Daya yang dibutuhkan maksimal sebesar $150 \mathrm{Watt}$ dimana daya yang sesuai dengan kapasitas listrik di kios pedagang. Waktu sealing bervariasi dari 2 detik hingga 9 detik disesuaikan dengan bahan plastik yang digunakan.

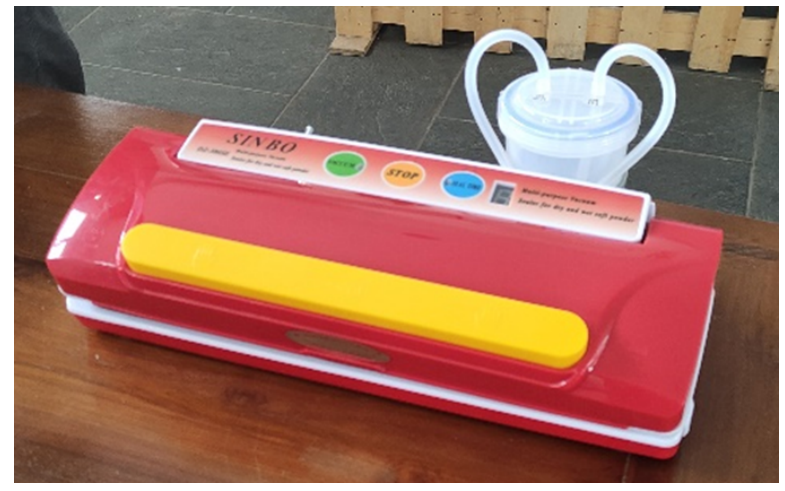

Gambar 3 Vacuum sealer $30 \mathrm{~cm}$ 


\section{3 | HASIL KEGIATAN}

Hasil kegiatan dibagi menjadi tiga kategori yaitu hasil kegiatan administrasi, hasil kegiatan studi lapang, dan hasil pemberian wawasan pengemasan, sebagai berikut.

\section{Hasil Administrasi}

Berdasarkan informasi yang diperoleh dari Badan Kesatuan Bangsa, Penanggulangan Bencana, dan Perlindungan Masyarakat (BKBPB Linmas) Kota Surabaya, syarat-syarat dalam mengajukan kegiatan yaitu:

1 Surat pengantar dari perguruan tinggi

2 Proposal kegiatan

3 KTP ketua pengabdi

4 Surat tugas

5 Surat kesediaan mitra kegiatan (dalam hal ini Camat Bulak yang menaungi SIB)

Setelah persyaratan tersebut diperoleh, Langkah selanjutnya adalah mengunggah dokumen pada laman https://bpblinmas. surabaya.go.id/kesbang/ Jika persyaratan lengkap dan tidak ada revisi, BKBPB Linmas Kota Surabaya menerbitkan surat rekomendasi.

\section{Hasil Studi Lapangan}

Studi lapang bertujuan untuk mengetahui permasalahan dan kebutuhan pedagang UKM di SIB. Studi lapang dilaksanakan dengan metode wawancara secara langsung kepada 6 dari total 9 pedagang SIB dengan pertanyaan yang meliputi aspek:

1 Lama berjualan

2 Kepemilikan vacuum sealer

3 Alat yang digunakan dalam mengemas produk

4 Daya tahan produk dengan metode pengemasan saat ini

5 Keinginan untuk memiliki vacuum sealer

Hasil wawancara diolah dan disajikan sebagai grafik pada Gambar 4-8. Pedagang yang telah berjualan lebih dari 5 tahun di SBI; bahkan sudah berjualan sejak SBI berdiri 8 tahun lalu; sebanyak $70 \%$ dengan produk hasil olahan ikan seperti ditunjukkan pada Gambar 4

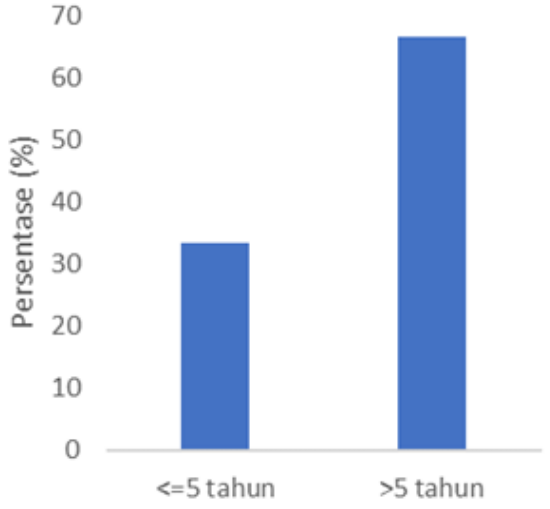

Gambar 4 Lama berjualan 
Namun, dari semua pedagang yang diwawancara; yang berjualan kurang dan lebih dari 5 tahun; tak satupun yang menggunakan teknik pengemasan vacuum sealer, seperti ditunjukkan pada Gambar 5 Setengah dari jumlah pedagang masih menggunakan hand-sealer dan stapler, sisanya menggunakan tas plastik dan stapler, pada Gambar 6

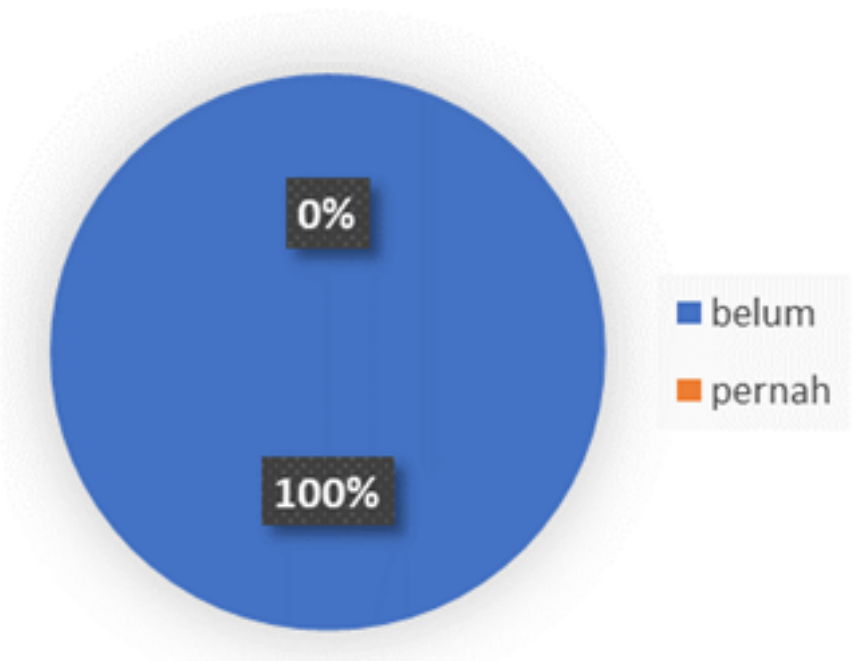

Gambar 5 Kepemilikan vacuum sealer

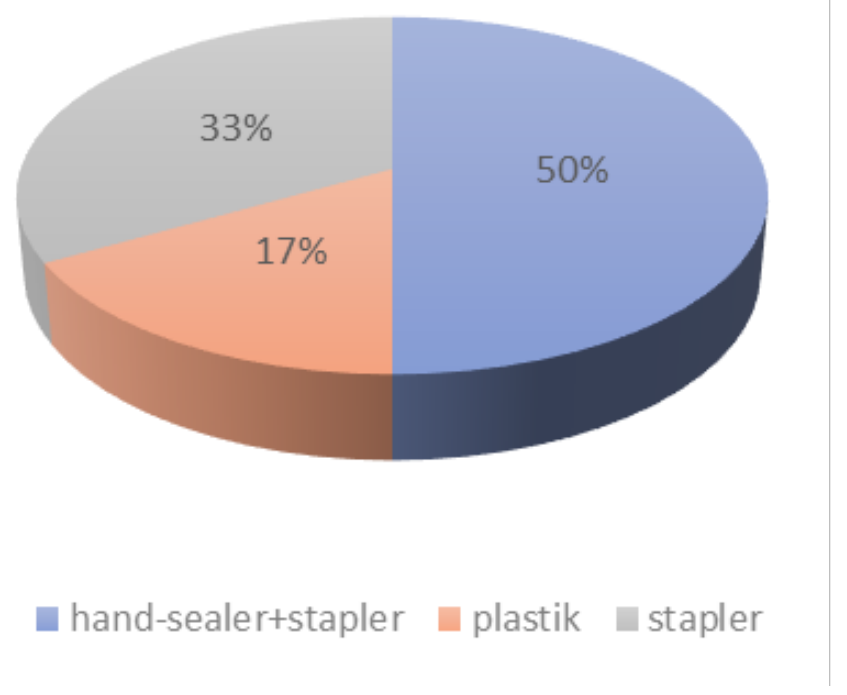

Gambar 6 Alat pengemasan saat ini

Berdasarkan Gambar 6 50\% penjual telah menggunakan hand-sealer dan stapler. Adapun produk yang menggunakan hand-sealer adalah produk kerupuk seperti yang terlihat pada Gambar $7 \mathrm{a}$ dan $7 \mathrm{~b}$ Sedangkan produk yang menggunakan stapler saja biasanya jenis ikan kering seperti Gambar 8 


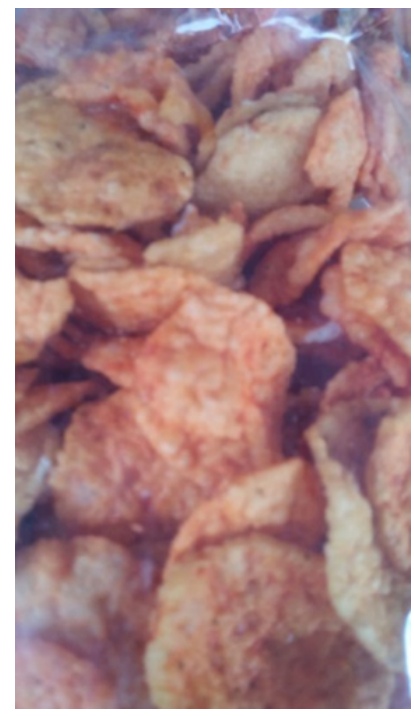

(a)

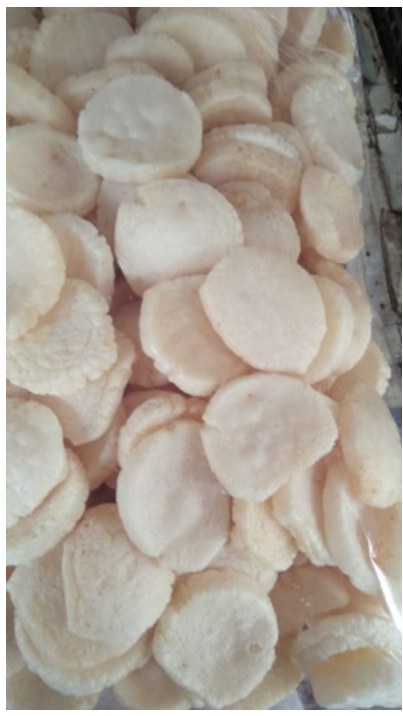

(b)

Gambar 7 Produk kerupuk dengan pengemasan hand-sealer

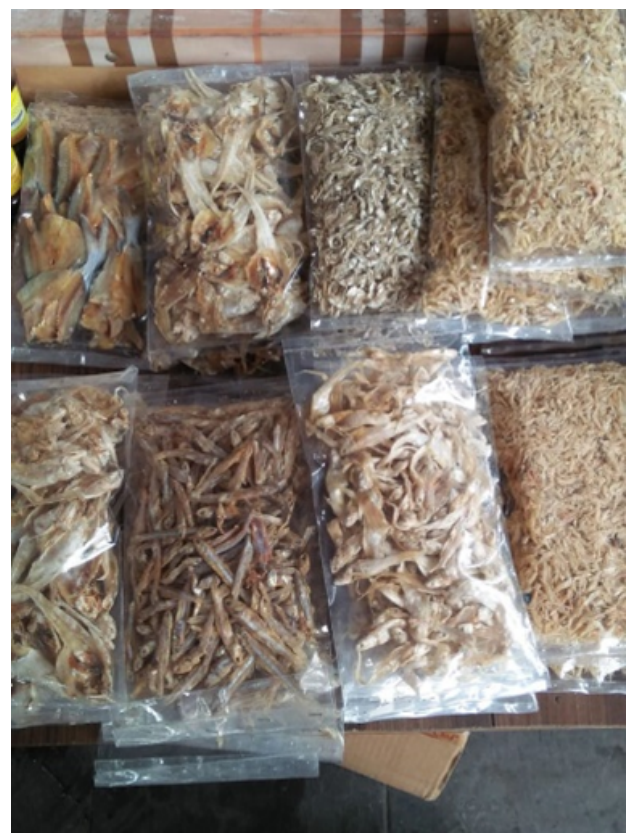

Gambar 8 Produk ikan kering dikemas dengan stapler

Teknik pengemasan yang mereka gunakan saat ini mempunyai kelemahan, daya tahan produk, yang merugikan pembeli dan pedagang SBI. 70\% pedagang mengaku daya tahan produk maksimal hanya 1 minggu dan sisanya hanya 3 hari, Gambar 9

Oleh karena itu, 83\% pedagang sangat ingin memiliki dan menerapkan metode pengemasan vacuum sealer pada produk yang mereka jual. Namun, terdapat $17 \%$ pedagang yang menolak untuk menggunakan vacuum sealer (Gambar 10 , karena produk yang dijual berupa kerupuk ikan yang telah digoreng. Mereka khawatir pengemasan vakum akan menghilangkan udara sehingga kerupuk akan tertekan, pecah dan rusak. 


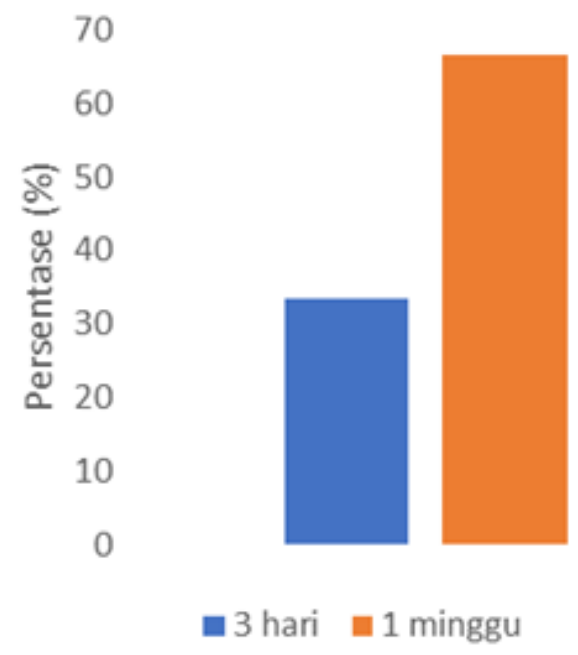

Gambar 9 Daya tahan produk dengan alat saat ini

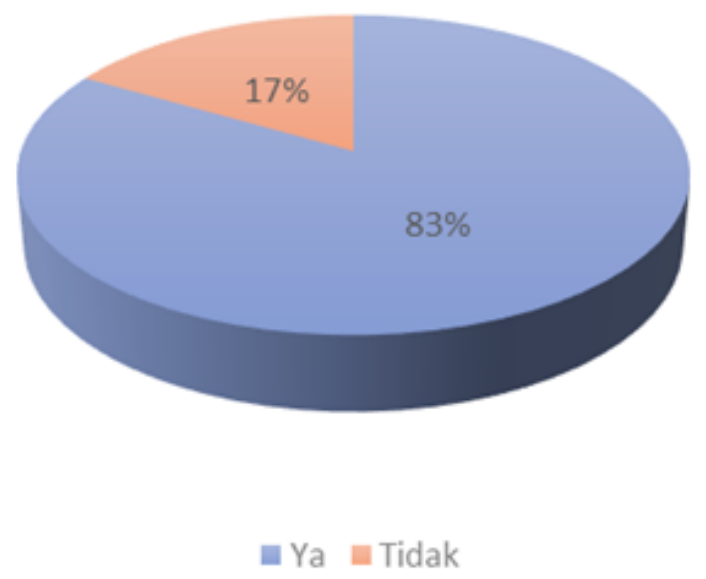

Gambar 10 Keinginan memiliki vacuum sealer

Berdasarkan hasil wawancara ini, kemudian tim pengabdian bekerja memberikan wawasan, penyuluhan dan menerapkan metode pengemasan vacuum sealer. Proses dan hasil kegiatan pemberian wawasan dilaporkan di bawah ini.

\section{Hasil Penyuluhan}

Kegiatan penyuluhan ini bertujuan untuk memperkenalkan dan mengaplikasikan teknologi vacuum sealer kepada para pedagang SBI sehingga produk olahan ikan dapat bertahan lama. Rangkaian acara kegiatan penyuluhan meliputi:

\section{Sambutan}

Sambutan diberikan oleh PPL Dinas Ketahanan Pangan dan dilanjutkan sambutan oleh kepala lab. Rekayasa Vibrasi dan Sistem Otomotif seperti yang terlihat pada Gambar 11 PPL Dinas Ketahanan Pangan menyampaikan rasa terimakasih kepada tim pengabdi karena telah mengadakan kegiatan yang bermanfaat bagi pedagang SIB. Kegiatan ini juga disambut hangat oleh para pedagang SIB dan mereka antusias selama proses kegiatan. 


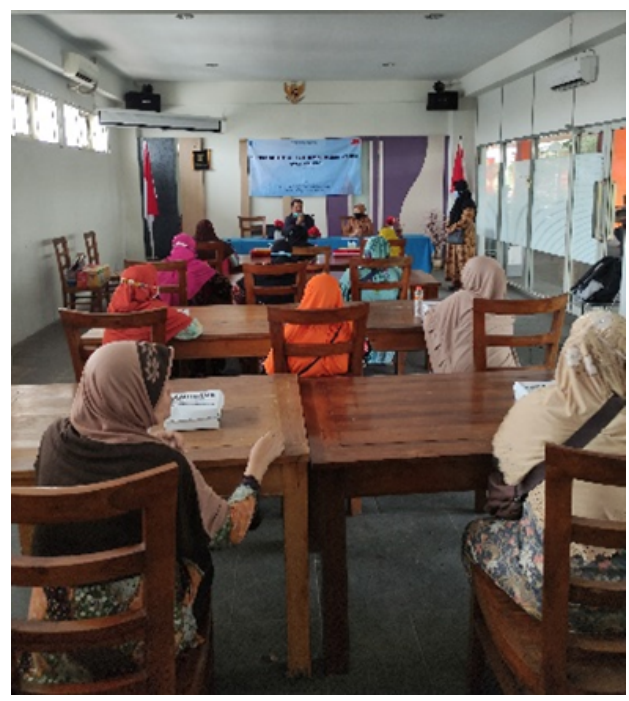

Gambar 11 Acara sambutan

2 Penyampaian kegunaan vacuum sealer

Setelah sambutan berakhir, salah satu anggota tim menyampaikan definisi, keuntungan serta jenis produk yang dapat dikemas dengan teknik vacuum sealer seperti yang terlihat pada Gambar 12 Banyak pedagang yang belum mengetahui mengenai teknik pengemasan ini.

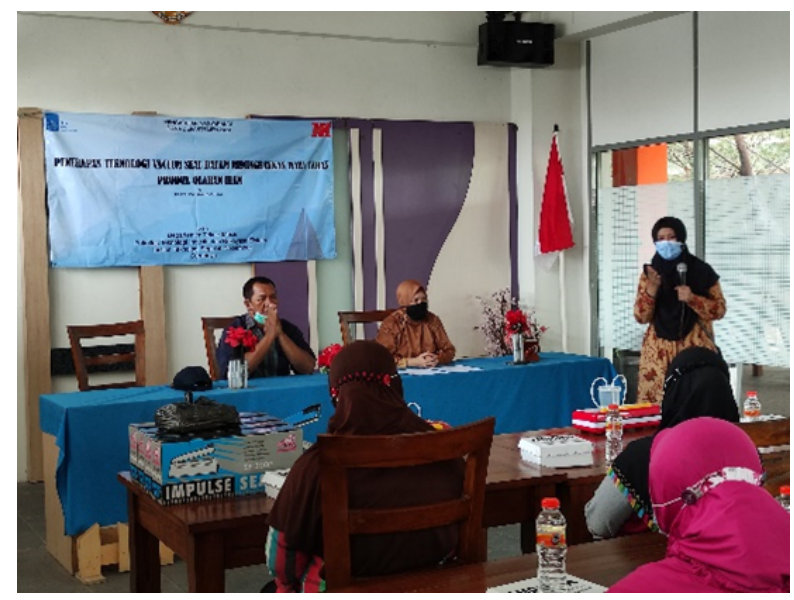

Gambar 12 Penyuluhan dan pemberian wawasan mengenai vacuum sealer

Alat vacuum sealer bekerja dalam 2 tahap, yaitu pertama akan menghisap semua udara yang ada di dalam kemasan hingga vakum. Langkah kedua, kemudian alat akan melakukan pengelasan plastik atau penyegelan yang disebut sebagai sealing. Pengemasan ini dapat digunakan pada produk cair maupun padat.

Selain itu, manfaat pengemasan vacuum sealer yang disampaikan kepada pedagang SBI, yaitu:

i. Produk ikan kering jadi awet

ii. Produk makanan ikan menjadi lebih segar

iii. Produk makanan ikan menjadi lebih higienis karena tidak terbuka 
iv. Bentuk menjadi fleksibel dan tidak bocor sehingga pembeli merasa nyaman

v. Aroma dari ikan tidak terlalu menyengat saat dikemas dengan baik

vi. Tampilan produk menarik

3 Penyampaian cara kerja alat dan praktik

Cara kerja alat vacuum sealer disampaikan oleh Ari Kurniawan (Gambar 13 dan 14 , dengan prosedur yang jelas sebagai berikut

i. Mempersiapkan alat dan menghubungkan ke sumber listrik seperti terlihat pada Gambar 13

ii. Menyalakan alat dengan menekan tombol ON

iii. Saat alat sudah siap, masukkan selang besi ke dalam plastik kemasan

iv. Setelah posisi plastik kemasan pas dan tutup sudah rapat, tekan tombol vakum sehingga kompressor bekerja memulai proses vakum.

v. Setelah plastik kemasan menjadi hampa udara, tekan tombol seal sehingga alat akan menyegel (seal) seperti kegiatan pada Gambar 14 dan produk siap dijual.

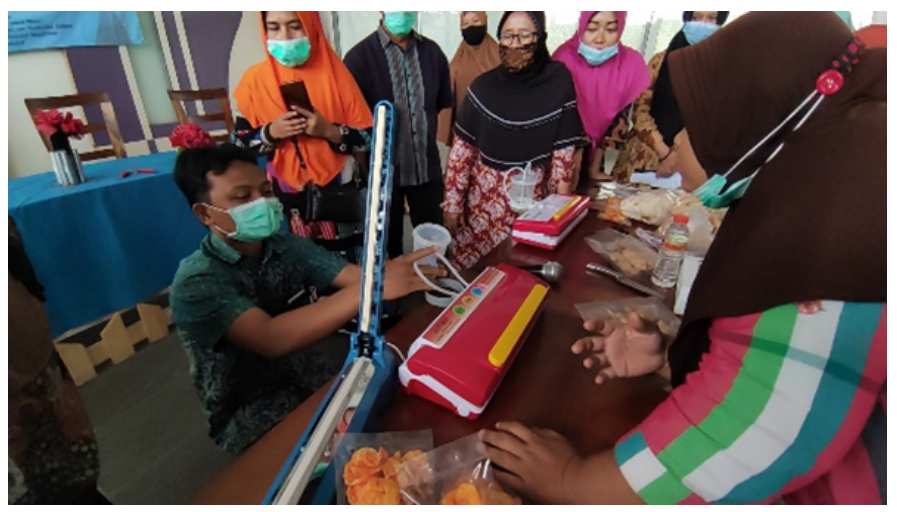

Gambar 13 Persiapan alat

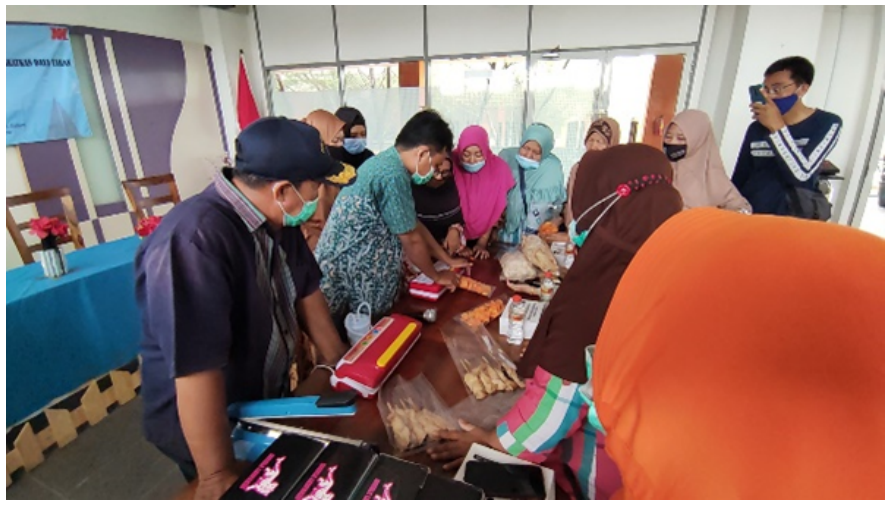

Gambar 14 Proses sealing (penyegelan plastik) 
Prosedur pengemasan diberikan dan didemonstrasikan dengan baik oleh tim. Kemudian masing-masing pedagang yang hadir mencoba menggunakan alat vacuum sealer dengan mengikuti prosedur yang telah dipelajari.

Setiap pedagang mempunyai kesempatan mencoba 2-3 kali di bawah pengawasan tim. Pedagang yang hadir membawa produknya masing-masing, sehingga pedagang dapat langsung mempraktekkan pengemasan produk dengan alat vacuum sealer. Pedagang yang hadir sangat antusias mencoba alat pengemasan baru ini seperti yang terlihat pada Gambar 15 . Hal ini terlihat karena para pedagang membawa beberapa jenis produk mereka. Mereka ingin tahu perbedaan hasil pengemasan untuk jenis produk mereka yang bermacam-macam, sebagai contoh pengemasan ikan patin asap yang ditunjukkan pada Gambar 16

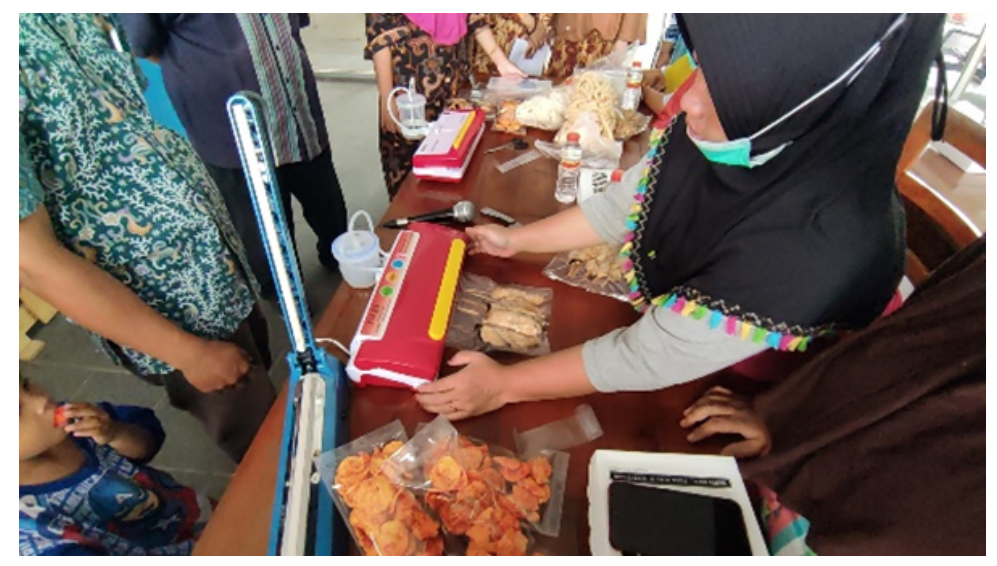

Gambar 15 Praktik langsung oleh pedagang

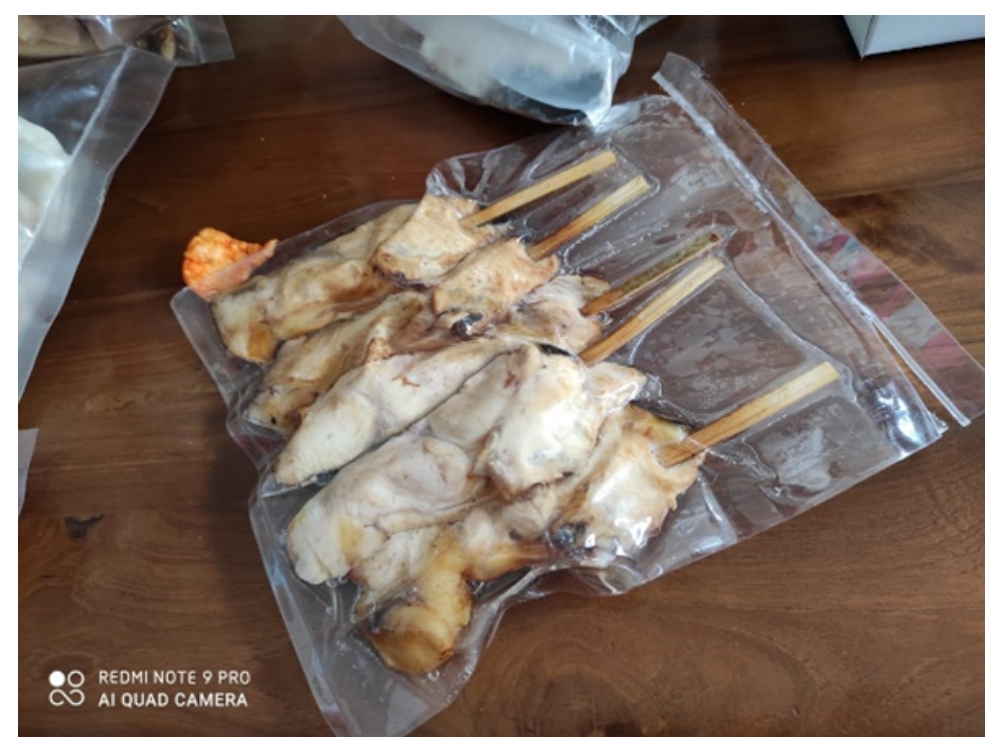

Gambar 16 Hasil percobaan pengemasan ikan patin asap dengan vacuum sealer

Adapun yang perlu diperhatikan dalam proses penyegelan (seal) adalah penentuan lama waktu sealing (2-8 detik) disesuaikan dengan ketebalan kemasan plastik yang digunakan. Beberapa hal yang diakibatkan karena ketidaksesuaian tersebut adalah plastik tidak tersegel dengan baik, bahkan plastik akan meleleh saat disegel jika waktu sealing terlalu lama sehingga akan kemasan akan terbuka seperti pada Gambar 17 


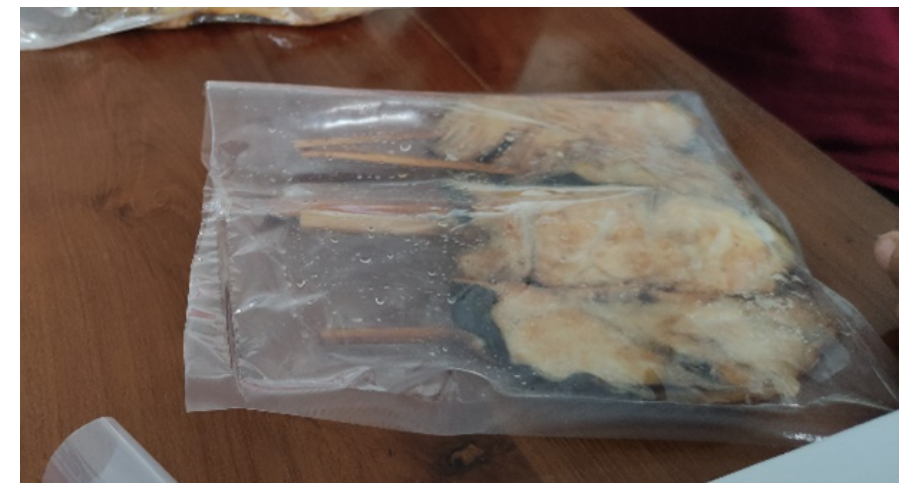

Gambar 17 Kesalahan penentuan waktu sealing

\section{Penyerahan alat}

Kegiatan pengabdian ini kemudian ditutup dengan penyerahan alat vacuum sealer kepada para pedagang, yang diberikan oleh kepala lab. Rekayasa Vibrasi dan Sistem Otomotif disaksikan oleh PPL Dinas Ketahanan Pangan seperti terlihat pada Gambar 18

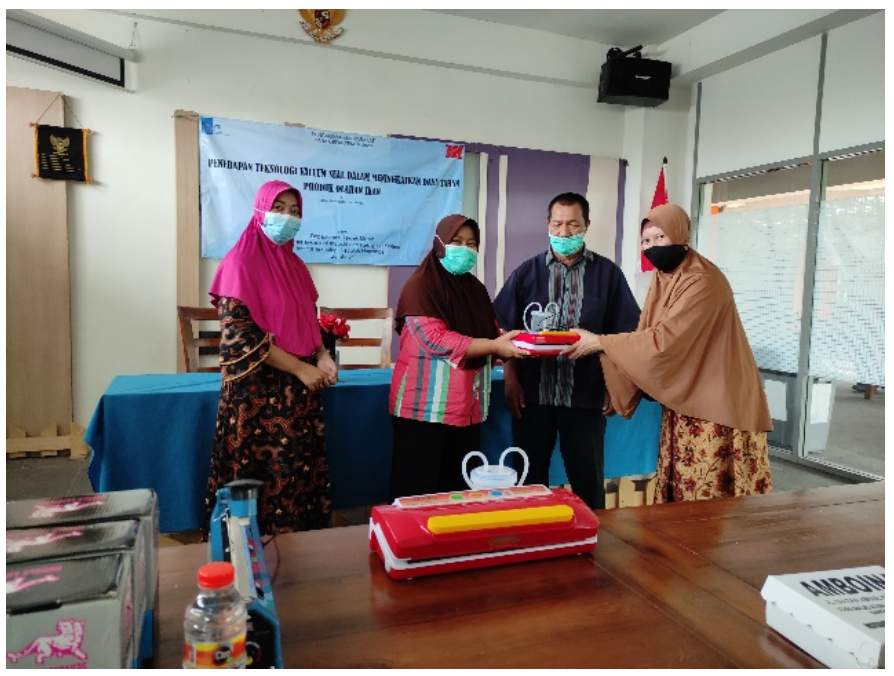

Gambar 18 Penyerahan alat

\section{4 | KESIMPULAN}

Kegiatan pengabdian untuk memperkenalkan dan pengaplikasikan pengemasan vakum dengan vacuum sealer kepada pedagang SBI telah berhasil dilaksanakan. Teknik pengemasan ini merupakan pengemasan terbaik untuk produk ikan asap, ikan segar, dan ikan kering karena dapat memperpanjang daya tahan produk. Kegiatan diawali dengan proses pencarian data yang dilakukan dengan metode wawancara kepada 6 dari 9 pedagang SIB. Dari data tersebut, tim pengabdian bekerja dan memulai proses penyuluhan. Kegiatan penyuluhan diawali dengan penjelasan alat dan manfaatnya. Lalu prosedur penggunaan alat dijabarkan dan didemonstrasikan secara jelas. Para pedagang juga mendapat kesempatan untuk mencoba proses vacuum seal pada produk mereka masing-masing. Pedagang sangat antusias dan senang. Merekapun berharap proses pengemasan ini dapat meningkatkan jumlah penjualan hingga ke pasar nasional. 
Adapun dampak ekonomi yang dialami oleh pedagang SIB masih belum terlihat signifikan. Hal ini disebabkan adanya faktor pandemi COVID-19 yang berpengaruh terhadap kebijakan kegiatan pariwisata di daerah SIB Bulak. Jumlah wisatawan yang berkunjung masih belum normal. Adapun langkah yang harus dilakukan oleh pedagang agar dapat meningkatkan penjualan yaitu dengan memanfaatkan media sosial atau menggunakan aplikasi ojek online sehingga lebih banyak orang yang dapat membeli produk tersebut.

Sedangkan ketahanan ikan asap setelah dikemas dengan vacuum sealer dapat mencapai 10 hari dari yang awalnya hanya 5 hari jika diletakkan pada mesin pendingin. Kemudian, ikan asap tidak mengeluarkan cairan yang banyak dengan kemasan vakum dibandingkan dengan kemasan plastik biasa.

\section{5 | UCAPAN TERIMA KASIH}

Pengabdian masyarakat ini didukung oleh Direktorat Riset dan Pengabdian kepada Masyarakat skema Dana Departemen tahun 2020 sesuai Surat Perjanjian Pelaksanaan Pengabdian Masyarakat No: 1818/PKS/ITS/2020.

\section{Pustaka}

[1] Eko Nurcahya Dewi and Ratna Ibrahim. "MUTU DAN DAYA SIMPAN FILLET DENDENG IKAN NILA MERAH YANG DIKEMAS HAMPA UDARA DENGAN VACUUM SEALER SKALA RUMAH TANGGA (The Quality And Shelf Life Of Dried Spiced Nile Tilapia Fillet Packed By House Scale Vacuum Sealer)". in: Jurnal Saintek Perikanan 4.1 (2008), pages 69-78.

[2] Helmi Harris and M Fadli. "PENENTUAN UMUR SIMPAN (SHELF LIFE) PUNDANG SELUANG (Rasbora sp) YANG DIKEMAS MENGGUNAKAN KEMASAN VAKUM DAN TANPA VAKUM (Determination of Pundang Seluang (Rasbora sp) Shelf Life which Packed using Vacuum and Non Vacuum Packaging)". in: Saintek Perikanan: Indonesian Journal of Fisheries Science and Technology 9.2 (2014), pages 53-62. DOI: https://doi.org/10.14710/ijfst.9.2.53-62

[3] Dea Tio Mareta and Shofia Nur Awami. "Pengemasan produk sayuran dengan bahan kemas plastik pada penyimpanan suhu ruang dan suhu dingin". in: Mediagro 7.1 (2011), pages 26-40. DOI: $10.31942 / \mathrm{md} . v 711.530$

[4] Peraturan Pemerintah Nomor. "tahun 1999 tentang Label dan Iklan Pangan". in: Lembaran Negara Nomor 131 (69). (accessed: 16.05.2021).

[5] Muhammad Nur. "Pengaruh cara pengemasan, jenis bahan pengemas, dan lama penyimpanan terhadap sifat kimia, mikrobiologi, dan organoleptik sate bandeng (Chanos chanos)". in: Jurnal Teknologi \& Industri Hasil Pertanian 14.1 (2012), pages $1-11$.

[6] Akbar Zaelani. PENGEMASAN PRODUK PERIKANAN. 2016. URL: http://penyuluhankelautanperikanan.blogspot.com/ 2016/10/pengemasan-produk-perikanan_6.html (accessed: 15.05.2021).

Cara mengutip artikel ini: Daman A. A. A., Hendrowati W., Saputra A. K., Nurahmi L., (2021), Penerapan Teknologi Vacuum Seal untuk Meningkatkan Daya Tahan Produk Olahan Ikan di Sentra Ikan Bulak, Sewagati: Jurnal Pengabdian Kepada Masyarakat, 5(3):257-268. 